\title{
Arylazoazines and arylazoazoles as interesting disperse dyes: Recent developments with emphasis on our contribution laboratory outcomes
}

\author{
Saleh Mohammed Al-Mousawi *, Morsy Ahmed El-Apasery, and Mohamed Hilmy Elnagdi \\ Department of Chemistry, Faculty of Science, Kuwait University, Safat 13060, Kuwait \\ ${ }^{*}$ Corresponding author at: Department of Chemistry, Faculty of Science, Kuwait University, Safat 13060, Kuwait. \\ Tel.: +965.24985547. Fax: +965.24816482. E-mail address: saleh.almousawi@yahoo.com (S. M. Al-Mousawi).
}

\section{REVIEW INFORMATION}

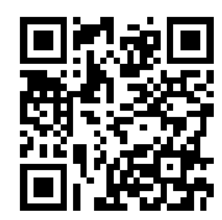

DOI: $10.5155 /$ eurjchem.5.1.192-200.883

Received: 23 July 2013

Received in revised form: 04 October 2013

Accepted: 06 October 2013

Online: 31 March 2014

\section{KEYWORDS}

Disperse dyes

Arylazoazoles

Arylazoazines

Polyester fabrics

Biological activity

Microwave irradiation

\section{Introduction}

Arylazoazines have replaced arylazopyrazoles as disperse monoazo dyes of superior properties. Among these dyes (1-4) are commercially available (Figure 1) [1-5]. In recent years, we have placed emphasis on developing efficient syntheses of new substitutes aryl and heteroarylazoazines and azoles as potential antimicrobial dyes emphasizing on utility of green methodologies whenever this was possible. In the following article, we survey these results as well as some recent related work worldwide.

This study aims to shed light on the potential of arylazonicotinate, pyrido[3,2,c]cinnolines, pyrido[2,3-d]pyrimidinones, arylazopyridones, arylazothienopyridones, arylazothienopyridazines, arylazopyrazoles and pyrazolopyrimidines as antimicrobial disperse dyes for hydrophobic fibers. Thus, encouraging developing large scale preparations of these products as well as commercial utility in dyeing fabrics having antimicrobial activity.

2. Synthetic approaches to arylazonicotinate, pyrido[3,2,c] cinnolines and pyrido $[2,3-d]$ pyrimidinones derivatives

In 1999, Elnagdi et al. [6] reported that coupling enaminones, 1, with aromatic diazonium salts affords arylhydrazonals, 2 , that subsequently condensed with active methylene nitriles to yield pyridazine imines, 3 [7]. However, with the help of X-ray crystal structure determination as well as ${ }^{13} \mathrm{C}$ NMR data it was realized that the reaction of condensing compound $\mathbf{2}$ with active methylene nitriles produces either pyridazinones or arylazonicotinates based on the reaction conditions [8,9]. It is believed that the pathways for these processes involve initial reaction of compound $\mathbf{2}$ with active methylene nitriles to yield the hydrazono-enone, $\mathbf{4}$, that then cyclizes to generate the pyran-imine, $\mathbf{5}$. In the absence of ammonium ion, compound $\mathbf{5}$ undergoes a Dimroth type rearrangement to yield compound 7 (Scheme 1) (Table 1) $[10,11]$. Subsequently, Al-Mousawi et al. has found that in presence excess amount of ammonium acetate the amino derivative 9 is formed. In case of presence excess amount of ammonium acetate pyran-imine, $\mathbf{5}$, is attacked by $\mathrm{NH}_{3}$ ion yielding acyclic amidine $\mathbf{8}$ that then cyclizes followed by water elimination to yield compound 9 [11-13]. Previously, it was noted in the literature that in some cases pyridazinones $\mathbf{1 0}$ are the reaction products (Figure 2-4) [14-19].

In contrast, 3-oxo-3-substituted-2-arylhydrazonals react with active methylene nitriles to afford the novel 2,6dihydropyrido[3,2,c]cinnolines, $\mathbf{1 2}$. These substances are believed to be formed via a $6 \pi$-electrocyclization reaction of the initially formed arylazo nicotinate $\mathbf{7}$, that generates the tricyclic intermediate product 11, which then aromatizes to produce the cinnoline derivatives, 12 (Scheme 2) [9,11,12]. 


\begin{tabular}{|c|c|c|c|c|c|}
\hline Compound & $\mathbf{R}$ & $\mathbf{A r}$ & $\mathbf{X}$ & M.p. $\left({ }^{\circ} \mathrm{C}\right)$ & Yield (\%) \\
\hline $3 a$ & $\mathrm{C}_{6} \mathrm{H}_{5}$ & $\mathrm{C}_{6} \mathrm{H}_{4} \mathrm{NO}_{2}-p$ & $\mathrm{CO}_{2} \mathrm{Et}$ & $199-201$ & 74 \\
\hline $3 b$ & Thien-2-yl & $\mathrm{C}_{6} \mathrm{H}_{4} \mathrm{NO}_{2}-p$ & $\mathrm{CO}_{2} \mathrm{Et}$ & $170-172$ & 67 \\
\hline $3 c$ & Fur-2-yl & $\mathrm{C}_{6} \mathrm{H}_{4} \mathrm{NO}_{2}-p$ & $\mathrm{CO}_{2} \mathrm{Et}$ & $242-244$ & 75 \\
\hline $7 a$ & $\mathrm{C}_{6} \mathrm{H}_{5}$ & $\mathrm{C}_{6} \mathrm{H}_{4} \mathrm{CH}_{3}-p$ & $\mathrm{CO}_{2} \mathrm{Et}$ & $180-182$ & 84 \\
\hline $7 b$ & $\mathrm{C}_{6} \mathrm{H}_{5}$ & $\mathrm{C}_{6} \mathrm{H}_{4} \mathrm{CH}_{3}-p$ & $\mathrm{CONH}_{2}$ & $276-277$ & 85 \\
\hline $7 c$ & $\mathrm{C}_{6} \mathrm{H}_{4} \mathrm{NO}_{2}-p$ & $\mathrm{C}_{6} \mathrm{H}_{5}$ & $\mathrm{CN}$ & $276-278$ & 85 \\
\hline $7 d$ & $\mathrm{C}_{6} \mathrm{H}_{4} \mathrm{CH}_{3}-p$ & $\mathrm{C}_{6} \mathrm{H}_{5}$ & $\mathrm{CSNH}_{2}$ & $166-168$ & 72 \\
\hline $7 e$ & $\mathrm{CH}_{3}$ & $\mathrm{C}_{6} \mathrm{H}_{5}$ & $\mathrm{CONH}_{2}$ & $>300$ & 74 \\
\hline $7 \mathrm{f}$ & $\mathrm{C}_{6} \mathrm{H}_{5}$ & $\mathrm{C}_{6} \mathrm{H}_{5}$ & & $>300$ & 95 \\
\hline $7 \mathrm{~g}$ & $\mathrm{C}_{6} \mathrm{H}_{5}$ & $\mathrm{C}_{6} \mathrm{H}_{5}$ & $\mathrm{CN}$ & 153 & 95 \\
\hline $7 \mathrm{~h}$ & $\mathrm{C}_{6} \mathrm{H}_{5}$ & $\mathrm{C}_{6} \mathrm{H}_{5}$ & $\mathrm{CO}_{2} \mathrm{Et}$ & $188-190$ & 87 \\
\hline $7 \mathrm{i}$ & $\mathrm{C}_{6} \mathrm{H}_{5}$ & $\mathrm{C}_{6} \mathrm{H}_{5}$ & $\mathrm{CSNH}_{2}$ & 190 & 98 \\
\hline $7 j$ & $\mathrm{C}_{6} \mathrm{H}_{5} \mathrm{Ph}-p$ & $\mathrm{C}_{6} \mathrm{H}_{5}$ & $\mathrm{CN}$ & 145 & 95 \\
\hline $7 \mathrm{k}$ & $\mathrm{C}_{6} \mathrm{H}_{5} \mathrm{Ph}-p$ & $\mathrm{C}_{6} \mathrm{H}_{5}$ & $\mathrm{CONHNH}_{2}$ & 237 & 95 \\
\hline 71 & Thien-2-yl & $\mathrm{C}_{6} \mathrm{H}_{5}$ & & 242 & 98 \\
\hline $7 \mathrm{~m}$ & Fur-2-yl & $\mathrm{C}_{6} \mathrm{H}_{5}$ & $\mathrm{CN}$ & 214 & 95 \\
\hline $7 n$ & $\mathrm{C}_{6} \mathrm{H}_{5} \mathrm{Cl}-p$ & $\mathrm{C}_{6} \mathrm{H}_{5}$ & $\mathrm{CO}_{2} \mathrm{Et}$ & $193-195$ & 89 \\
\hline 70 & $\mathrm{C}_{6} \mathrm{H}_{4} \mathrm{OCH}_{3}-p$ & $\mathrm{C}_{6} \mathrm{H}_{5}$ & $\mathrm{CO}_{2} \mathrm{Et}$ & $174-176$ & 75 \\
\hline $7 p$ & Pyrrol-2-yl & $\mathrm{C}_{6} \mathrm{H}_{5}$ & $\mathrm{CO}_{2} \mathrm{Et}$ & $202-204$ & 60 \\
\hline $7 q$ & Pyrazin-2-yl & $\mathrm{C}_{6} \mathrm{H}_{4} \mathrm{CH}_{3}-p$ & $\mathrm{CO}_{2} \mathrm{Et}$ & $>300$ & 68 \\
\hline $7 r$ & & $\mathrm{C}_{6} \mathrm{H}_{5}$ & $\mathrm{CO}_{2} \mathrm{Et}$ & $188-190$ & 56 \\
\hline $9 a$ & $\mathrm{C}_{6} \mathrm{H}_{5}$ & $\mathrm{C}_{6} \mathrm{H}_{4} \mathrm{CH}_{3}-p$ & $\mathrm{CO}_{2} \mathrm{Et}$ & $210-212$ & 81 \\
\hline $9 b$ & $\mathrm{C}_{6} \mathrm{H}_{4} \mathrm{NO}_{2}-p$ & $\mathrm{C}_{6} \mathrm{H}_{5}$ & $\mathrm{CO}_{2} \mathrm{Et}$ & $200-202$ & 80 \\
\hline $9 c$ & $\mathrm{C}_{6} \mathrm{H}_{5}$ & $\mathrm{C}_{6} \mathrm{H}_{4} \mathrm{Cl}-p$ & $\mathrm{CO}_{2} \mathrm{Et}$ & $188-190$ & 68 \\
\hline $9 d$ & Naphthalene-2-yl & $\mathrm{C}_{6} \mathrm{H}_{4} \mathrm{Cl}-p$ & $\mathrm{CO}_{2} \mathrm{Et}$ & $89-90$ & 77 \\
\hline $10 \mathrm{a}$ & $\mathrm{C}_{6} \mathrm{H}_{4} \mathrm{CH}_{3}-p$ & $\mathrm{C}_{6} \mathrm{H}_{5}$ & $\mathrm{CO}_{2} \mathrm{Et}$ & $108-110$ & 55 \\
\hline $10 \mathrm{~b}$ & $\mathrm{C}_{6} \mathrm{H}_{4} \mathrm{CH}_{3}-p$ & $\mathrm{C}_{6} \mathrm{H}_{5}$ & $\mathrm{CONH}_{2}$ & $243-245$ & 52 \\
\hline $10 \mathrm{c}$ & $\mathrm{C}_{6} \mathrm{H}_{4} \mathrm{CH}_{3}-p$ & $\mathrm{C}_{6} \mathrm{H}_{5}$ & $\mathrm{CN}$ & $186-188$ & 64 \\
\hline $10 \mathrm{~d}$ & $\mathrm{C}_{6} \mathrm{H}_{5} \mathrm{Cl}-p$ & $\mathrm{C}_{6} \mathrm{H}_{5}$ & $\mathrm{CONH}_{2}$ & $211-213$ & 70 \\
\hline $12 \mathrm{a}$ & $\mathrm{H}$ & $\mathrm{C}_{6} \mathrm{H}_{4} \mathrm{NO}_{2}-p$ & $\mathrm{CO}_{2} \mathrm{Et}$ & $148-150$ & 62 \\
\hline $12 \mathrm{~b}$ & $\mathrm{H}$ & $\mathrm{C}_{6} \mathrm{H}_{4} \mathrm{Cl}-p$ & $\mathrm{CO}_{2} \mathrm{Et}$ & $143-148$ & 83 \\
\hline $12 \mathrm{c}$ & $\mathrm{H}$ & $\mathrm{C}_{6} \mathrm{H}_{4} \mathrm{NO}_{2}-p$ & $\mathrm{CONH}_{2}$ & 195 & 82 \\
\hline $12 \mathrm{~d}$ & $\mathrm{H}$ & $\mathrm{C}_{6} \mathrm{H}_{5}$ & & 150 & 98 \\
\hline $12 \mathrm{e}$ & $\mathrm{C}_{6} \mathrm{H}_{5}$ & $\mathrm{C}_{6} \mathrm{H}_{5}$ & $\mathrm{CONH}_{2}$ & 230 & 90 \\
\hline $12 \mathrm{f}$ & $\mathrm{C}_{6} \mathrm{H}_{5}$ & $\mathrm{C}_{6} \mathrm{H}_{5}$ & $\mathrm{CSNH}_{2}$ & 170 & 95 \\
\hline
\end{tabular}<smiles>CCn1c(O)c(N=Nc2cccc([N+](=O)[O-])c2)c(C)c(C#N)c1=O</smiles>

1- Greenish Yellow [37781-00-3] [1]<smiles>CCn1c(O)c(N=Nc2ccc(Cl)cc2[N+](=O)[O-])c(C)c(C#N)c1=O</smiles>

3- C.I. Disperse Yellow 211, 12755 [70528-90-4] [3]<smiles>Cc1c(/N=N/c2ccc(Cl)c(Cl)c2)c(O)n(C)c(=O)c1C#N</smiles>

2- C.I. Disperse Yellow 241, 128450 [83249-52-9] [2]

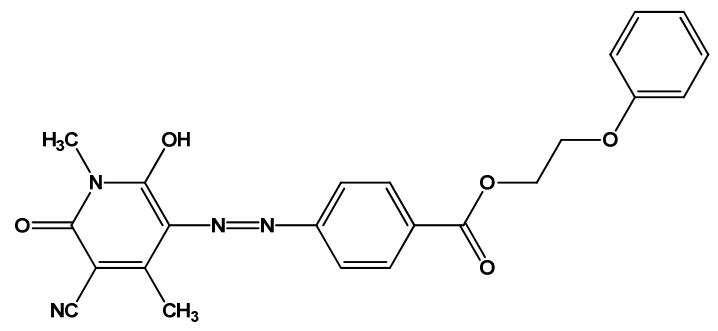

4- Greenish Yellow [88938-37-8] [4]

Figure 1. Examples of some commercially available dyes.

The formed aminonictinates 9a could be readily converted to ethyl 5-p-tolyldiazenyl)-2-(aminomethyleneamino)-6-phenyl nicotinate 13 via condensation with $\mathrm{N}, \mathrm{N}$-dimethylformamide dimethylacetal (DMFDMA) in presence of ammonium acetate.

Furthermore, the reaction of compound 13 with ammonium acetate in presence of acetic acid produces 7-phenyl-6-( $p$-tolyldiazenyl)pyrido[2,3- $d]$ pyrimidin-4(3H)-one, 14 (Scheme 3).

Compounds $\mathbf{7 a - e , ~} \mathbf{7 p}, \mathbf{7 q}$ and $\mathbf{9 a - d}$ were tested as disperse dyes on polyester fabrics, where $\mathbf{7 a - e}$, and $9 \mathbf{9 a - c}$ display yellow to brownish-green hues, in addition with very good washing and perspiration fastness and moderate light fastness [20]. 
<smiles>[R]C(=O)C=CNC</smiles><smiles>CC(Cl)C#[N+]</smiles><smiles>CCP</smiles><smiles></smiles>

2

<smiles>[R]C(=O)c1cc([X])c(=N)n(C2CCCCC2)n1</smiles>

3a-c 3a, $\mathrm{R}=\mathrm{C}_{6} \mathrm{H}_{5}, \mathrm{Ar}=\mathrm{C}_{6} \mathrm{H}_{4} \mathrm{NO}_{2}-\mathrm{p}, \mathrm{X}=\mathrm{CO}_{2} \mathrm{Et}$ b, $\mathrm{R}=$ Thien-2-yl, $\mathrm{Ar}=\mathrm{C}_{6} \mathrm{H}_{4} \mathrm{NO}_{2}-\mathrm{p}, \mathrm{X}=\mathrm{CO}_{2} \mathrm{Et}$ $c, \mathrm{R}=$ Fur-2-yl, $\mathrm{Ar}=\mathrm{C}_{6} \mathrm{H}_{4} \mathrm{NO}_{2}-\mathrm{p}, \mathrm{X}=\mathrm{CO}_{2} \mathrm{Et}$

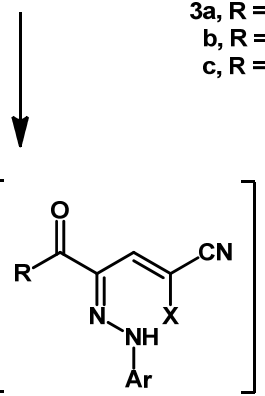

4

5

$\mathrm{NH}_{3}$<smiles>C=CC#CC</smiles>

1<smiles>[X]c1cc(N=N[Al])c([R])nc1O</smiles>

7a-r

$$
\begin{aligned}
& 7 \mathrm{a}, \mathrm{R}=\mathrm{C}_{6} \mathrm{H}_{5}, \mathrm{Ar}=\mathrm{C}_{6} \mathrm{H}_{4} \mathrm{CH}_{3}-\mathrm{p}, \mathrm{X}=\mathrm{CO}_{2} \mathrm{Et} \\
& \text { b, } \mathrm{R}=\mathrm{C}_{6} \mathrm{H}_{5}, \mathrm{Ar}=\mathrm{C}_{6} \mathrm{H}_{4} \mathrm{CH}_{3}-\mathrm{p}, \mathrm{X}=\mathrm{CONH}_{2} \\
& c, R=C_{6} \mathrm{H}_{4} \mathrm{NO}_{2}-\mathrm{p}, \mathrm{Ar}=\mathrm{C}_{6} \mathrm{H}_{5}, \mathrm{X}=\mathrm{CN} \\
& \text { d, } \mathrm{R}=\mathrm{C}_{6} \mathrm{H}_{4} \mathrm{CH}_{3}-\mathrm{p}, \mathrm{Ar}=\mathrm{C}_{6} \mathrm{H}_{5}, \mathrm{X}=\mathrm{CSNH}_{2} \\
& \text { e, } \mathrm{R}=\mathrm{CH}_{3}, \mathrm{Ar}=\mathrm{C}_{6} \mathrm{H}_{5}, \mathrm{X}=\mathrm{CONH}_{2}
\end{aligned}
$$<smiles>[R]C(O)=C(/C=C(\[X])C(=N)N)N=[Bi]</smiles><smiles>CCO</smiles><smiles>[R]C(=O)c1cc([X])c(=O)n([Ga]O[Na])n1</smiles>

10a, $\mathrm{R}=\mathrm{C}_{6} \mathrm{H}_{4} \mathrm{CH}_{3}-\mathrm{p}, \mathrm{Ar}=\mathrm{C}_{6} \mathrm{H}_{5}, \mathrm{X}=\mathrm{CO}_{2} \mathrm{Et}$ b, $\mathrm{R}=\mathrm{C}_{6} \mathrm{H}_{4} \mathrm{CH}_{3}-\mathrm{p}, \mathrm{Ar}=\mathrm{C}_{6} \mathrm{H}_{5}, \mathrm{X}=\mathrm{CONH}_{2}$ c, $\mathrm{R}=\mathrm{C}_{6} \mathrm{H}_{4} \mathrm{CH}_{3}-\mathrm{p}, \mathrm{Ar}=\mathrm{C}_{6} \mathrm{H}_{5}, \mathrm{X}=\mathrm{CN}$ d, $\mathrm{R}=\mathrm{C}_{6} \mathrm{H}_{5} \mathrm{Cl}-\mathrm{p}, \mathrm{Ar}=\mathrm{C}_{6} \mathrm{H}_{5}, \mathrm{X}=\mathrm{CONH}_{2}$

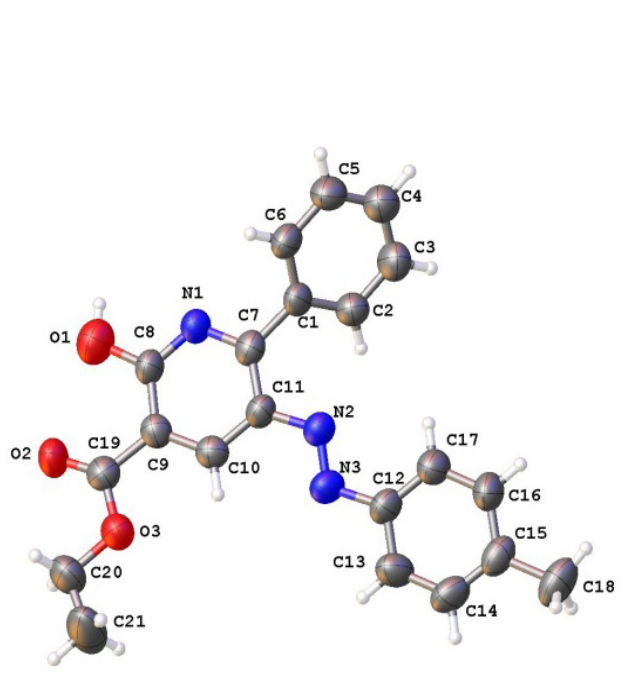

Figure 2. ORTEP drawing of compound 7a.

While $\mathbf{7 p}, \mathbf{7 q}$ and $\mathbf{9 d}$ display yellowish-orange to dark brown hues, and displayed excellent washing and perspiration fastness and moderate light fastness [21].
The antimicrobial activities of the synthesized dyes were screened against selected bacteria and fungi by the agar well diffusion method and their inhibition zones diameters, given in (Table 2), the tests reveal that all of the tested arylazonicotinates disperse dyes showed positive antimicrobial activities against at least one of the tested microorganisms. All of them showed strong activities ( $>10 \mathrm{~mm}$ inhibition zone) against Staphylococcus aureus.

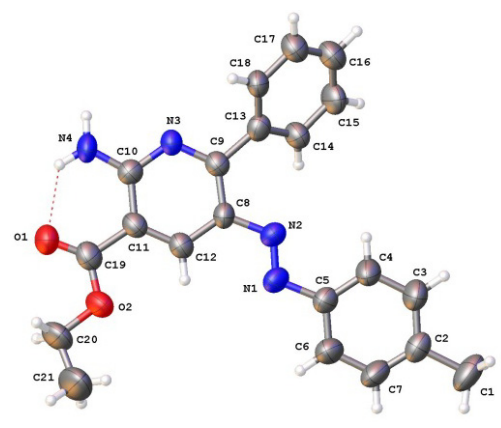

Figure 3. ORTEP drawing of compound 9a. 


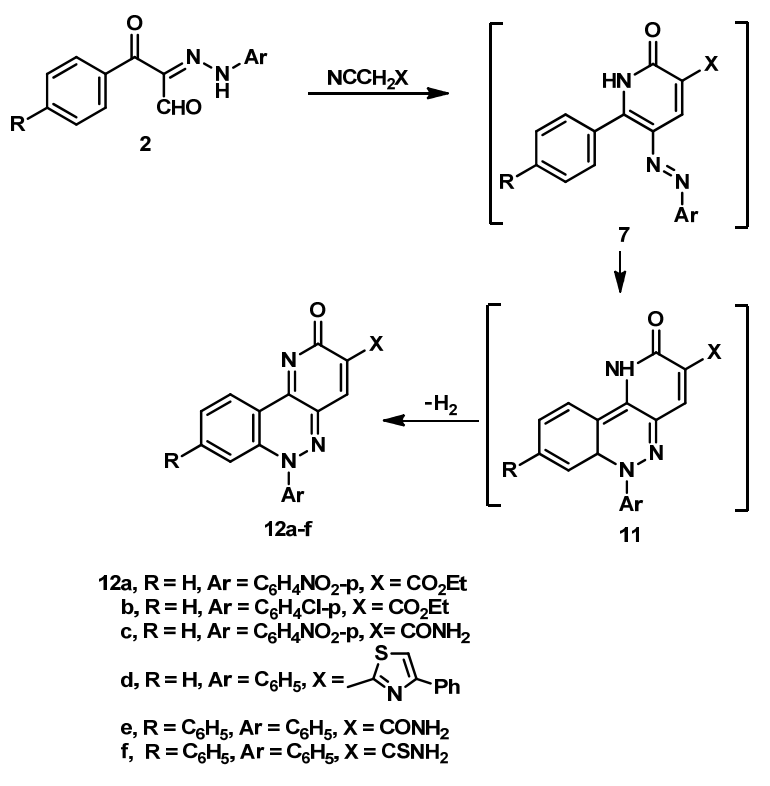

Scheme 2
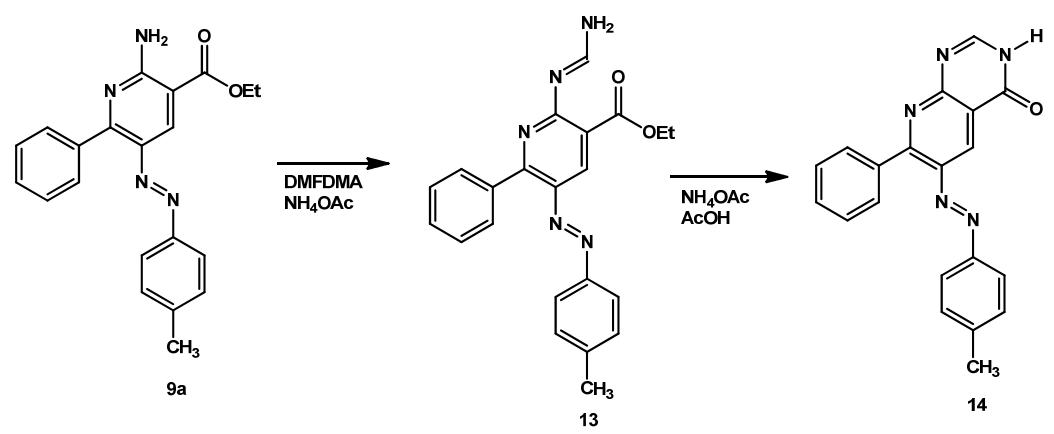

Scheme 3

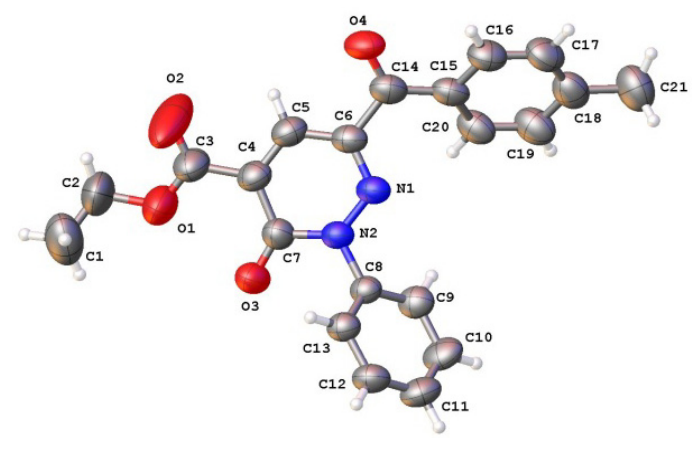

Figure 4. ORTEP drawing of compound 10a

Two of the dyes 7a and 9a, showed medium activities against Gram negative bacteria. Where most of the dyes showed no activities against the two strains of Gram negative bacteria used in the study.

Also the majority of the dyes showed weak to no activities at all with Bacillus subtilis. Only dye $\mathbf{7 d}$ showed significant inhibition zone $>10 \mathrm{~mm}$, against Candida albican. The other dye that showed medium activities against yeast is $\mathbf{7} \mathbf{c}$ while all the other dyes failed to affect the yeast growth. It is of value to mention here that after six days the inhibition zone did not show any difference in the size, yet the zone is not clear which indicates that the dye $\mathbf{9 b}$ did not kill the microorganisms, but rather had weakened their growth only, this is in comparison to dye $\mathbf{7 a}$ or to ampicillin as reference [20].

Also the inhibition zone diameter data for the disperse dyes $\mathbf{7 p}, \mathbf{7 q}$ and $\mathbf{9 d}$, given in Table 3 , shows that all of the tested dyes showed strong positive antimicrobial activities against at least one of the tested microorganisms. All disperse dyes show strong ability to inhibit the growth of Candida albicans which could be considered as interesting observations which needs further investigation. Disperse dye 9d showed the strongest inhibition zones among the five tested microorganisms, also all of these dyes showed cytotoxic effect even after five days of incubation, there were no growths recorded in the inhibited zone for all five tested microorganisms [21].

\section{Synthetic approaches to arylazopyridones and arylazothienopyridones}

As has been indicated arylazopyridones are already in the market 1-4 (Figure 1) and are prepared from pyridones 19a-q However, in the last decade, we could develop green syntheses of this pyridones utilizing microwave irradiating mixture of acetoacetic esters $\mathbf{1 5}$ and cyanoacetamides $\mathbf{1 6}$ as well as sonofication of these mixtures. 
Table 2. Diameter of the zones of inhibition of the dye $\mathbf{7 a - e}$, and $\mathbf{9 a}, \mathbf{b}$ a.

\begin{tabular}{|c|c|c|c|c|c|}
\hline \multirow[t]{2}{*}{ Dye no } & \multicolumn{5}{|c|}{ Inhibition zone diameter (Nearest mm) (Mean \pm SD) } \\
\hline & B. subtilis & S. aureus & E. coli & P. aeruginosa & C. albicans \\
\hline $7 a$ & $0.1 \pm 0.08$ & $15 \pm 0.02$ & 77 & - & - \\
\hline $7 \mathrm{~b}$ & $0.7 \pm 0.13$ & 16 & - & - & $7 \pm 0.07$ \\
\hline $7 c$ & - & $11 \pm 0.87$ & - & - & - \\
\hline $7 d$ & 0.1 & $16 \pm 0.08$ & - & - & $12 \pm 0.1$ \\
\hline $9 a$ & - & 13 & 7 & $7 \pm 0.05$ & - \\
\hline $9 \mathrm{~b}$ & - & $10 \pm 0.2$ & - & - & - \\
\hline Ampicillin b & $30 \pm 0.05$ & $46 \pm 0.7$ & $31 \pm 0.14$ & $17 \pm 0.07$ & - \\
\hline Cyloheximide $\mathrm{c}$ & & & & & - \\
\hline
\end{tabular}

a “-“: no inhibition, SD: Standard deviation.

b Ampicillin: Antibacterial $(100 \mathrm{mg} / \mathrm{mL})$

c Cycloheximide: Antifungal $(100 \mathrm{mg} / \mathrm{mL})$.

Table 3. Diameter of the zones of inhibition of the dye $\mathbf{7 p}, \mathbf{7 q}$ and $9 \mathrm{~d}$ a.

\begin{tabular}{l|llll}
\hline Dye no & \multicolumn{4}{l}{ Inhibition zone diameter (Nearest mm) } \\
\cline { 2 - 5 } & B. subtilis & S. aureus & E. coli & P. aeruginosa \\
\hline $7 \mathrm{p}$ & $0.7 \pm 0.7$ & - & $2.9 \pm 5.8$ & - \\
$7 \mathrm{q}$ & $12.4 \pm 0.2$ & $12.3 \pm 0.3$ & $12.7 \pm 0.4$ & $13 \pm 0.5$ \\
9d & $12.7 \pm 0.2$ & $11.7 \pm 0.4$ & $14.7 \pm 0.4$ & $16.1 \pm 0.5$ \\
Ampicillin b & $15 \pm 1$ & $18.4 \pm 3.5$ & $18.6 \pm 1.3$ & $16.0 \pm 0.5$ \\
Cyloheximide c & & & & \\
\hline
\end{tabular}

"-“: no inhibition, SD: Standard deviation.

b Ampicillin: Antibacterial $(100 \mathrm{mg} / \mathrm{mL})$

c Cycloheximide: Antifungal (100 mg/mL).

The obtained products and their yields are listed in Table 4. Alternately we could also show what mixtures of acetoacetic esters 15, cyanoacetic esters $\mathbf{1 7}$ and primary amines $\mathbf{1 8}$ gives directly the designed pyridones. However in our hands the multistep approach proved superiors since larger yields are obtained in this way. Practically, 1,2-dihydro-6-hydroxy-4methyl-2-oxo-3-pyridine carbonitrile 19o and other 1substituted derivatives have found wide application in the preparation of azo dyes, especially as disperse dyes for synthetic fibres [22-37].

There are many methods for the synthesis of compounds 19a-h. Condensation of methyl acetoacetate with appropriate amines and methyl cyanoacetate is one of the common methods [38,39]. Also basic condensation of $N$-alkylaceto acetamide with enamino- $\beta$-ketoesters lead to $2(1 H)$ pyridinones [40]. Another efficient method is heating cyanoacetamide and methyl acetoacetate in a microwave oven [41]. Balalaie et al. [42-48] have reported an efficient three component condensation of alkyl cyanoacetates, primary amines, and $\beta$-ketoesters with higher yields on the surface of silica gel, montmorillonite $\mathrm{K}-10$, zeolite, and acidic alumina under microwave irradiation, the obtained products $\mathbf{1 9 a}-\mathbf{h}$ in yields ranging from 91 to $93 \%$. These compounds have two tautomeric forms, and in solution there is a very fast equilibration between them [49]. Sakoma et al. [50] has also reported three component condensations of ethyl cyano acetate, primary amines, and ethyl acetoacetate without catalyst. The yields of the obtained products $190-\mathbf{q}$ ranged from 86 to $91 \%$. Pyridones 19a-q could be readily coupled with aromatic and heteroaromatic diazonium salts affording the corresponding aryl and heteroaromatic azopyridones 21a-t (Table 4). Sakoma et al. [50] and Ashkar et al. [51] have evaluated 3-( $p$-substituted phenylazo)-6-pyridone dyes 21a-d and $\mathbf{2 1} \mathbf{j}-\mathbf{t}$ as disperse dyes on polyester fabrics in order to examine the influence of substituent on the color of the prepared dyes. Sakoma et al. concluded that the exhaustion of the dyes was very good on polyester fabric with excellent wash and light fastness properties. These dyes, however, are noteworthy in their excellent affinity and intensity of color. Other outstanding characteristics of these dyes are that they give deep and bright hues with level dyeings. The bright hue might be attributed to the high planarity of the pyridone ring, because of the lower steric interaction of a five membered ring. The remarkable degree of levelness and brightness after washing is indicative of good penetration and the excellent exhaustion of these dyes for the polyester fabric due to the accumulation of polar groups [50].

As anticipated the aryl and heteroaromatic azopyridones 21e-i reacted with elemental sulphur either under heating with microwave or by using ultra sound or by conventional heating to yield the corresponding aminothienopyridinones 22a-e. Trials to develop condensed arylazopyridones have been made by Al-Mousawi et al. [52] and Al-Zaydi et al. [53]. Thus Al-Mousawi reported that reaction of compound 22d with dimethyl acetylenedicarboxylate afforded arylazoisoquinoline, 24, while Al-Zaydi et al. reported that compound 22e undergoes cycloaddition to acrylonitrile yielding isoquinolines, $\mathbf{2 6}$. However, up to date, no trial to test potential utility of the isoquinolines $\mathbf{2 2}$ and $\mathbf{2 6}$ as unique disperse dyes has been made (Scheme 4).

\section{Synthetic approaches to arylazothienopyridazines}

Other class of arylazoazines has also been synthesized by Al-Mousawi et al. [54-56]. Thus arylazopyridazinone 27 reacted with DMFDMA affording dihydropyridazine-4carbonitrile $\mathbf{2 8}$ that was readily converted into the pyrido[3,4d]pyridazine-4,5-diones $\mathbf{2 9}$ on treatment with ammonium acetate and acetic acid. Compound $\mathbf{2 7}$ readily reacted with elemental sulphur in the presence of few drops of piperidine yielding arylazoaminothienopyridazine $\mathbf{3 0}$ (Scheme 5) (Figure 5) [55]. Typical to the established behaviour of thieno pyridazines compounds, compound $\mathbf{3 0}$ reacted with $\mathrm{N}$-phenyl maleimide in a mixture of acetic acid and dioxane to yield pyrrolo[3,4-g]phthalazine 33 via intermediary of [4+2] cycloadducts 32. Reaction of compound 30 with DMFDMA afforded the corresponding amidine 34 (Figure 6) [56]. Upon heating compound $\mathbf{3 4}$ with ammonium acetate in presence of few drops of acetic acid affords the pyridopyridazine $\mathbf{3 7}$ via intermediary of [4+2] cycloadducts 36 .

Acylating of compound $\mathbf{3 0}$ in acetic acid resulted in the formation of acetylamino 35. Again up to date no trial to test potential utility of these compounds 27-37 as unique disperse dyes has been made.

\section{Synthetic approaches to arylazopyrazoles and pyrazolo pyrimidines}

Elnagdi et al. have, in the seventies, described efficient syntheses of compounds $\mathbf{3 8}$ and $\mathbf{3 9}$. 
Table 4. Yields of Compounds 19a-n, 21a-i, 22a-e, 24 and 26.

\begin{tabular}{|c|c|c|c|c|c|c|c|}
\hline Compound & $\mathbf{R}^{\mathbf{1}}$ & $\mathbf{R}^{2}$ & $\mathbf{R}^{3}$ & $\mathbf{X}$ & $\mathbf{A r}$ & M.p. $\left({ }^{\circ} \mathrm{C}\right)$ & Yield (\%) \\
\hline $19 a$ & $\mathrm{CH}_{3}$ & $\mathrm{CH}_{3}$ & $\mathrm{CH}_{3}$ & $\mathrm{H}$ & - & 285 & 93 \\
\hline $19 b$ & $\mathrm{C}_{2} \mathrm{H}_{5}$ & $\mathrm{C}_{2} \mathrm{H}_{5}$ & $\mathrm{CH}_{3}$ & $\mathrm{H}$ & - & 285 & 91 \\
\hline $19 \mathrm{c}$ & $\mathrm{C}_{2} \mathrm{H}_{5}$ & $\mathrm{CH}_{3}$ & $\mathrm{CH}_{3}$ & $\mathrm{H}$ & - & 285 & 91 \\
\hline $19 d$ & $\mathrm{CH}_{3}$ & $\mathrm{C}_{2} \mathrm{H}_{5}$ & $\mathrm{CH}_{3}$ & $\mathrm{H}$ & - & 285 & 91 \\
\hline $19 \mathrm{e}$ & $\mathrm{CH}_{3}$ & $\mathrm{CH}_{3}$ & $\mathrm{C}_{2} \mathrm{H}_{5}$ & $\mathrm{H}$ & - & 245 & 93 \\
\hline $19 \mathrm{f}$ & $\mathrm{C}_{2} \mathrm{H}_{5}$ & $\mathrm{C}_{2} \mathrm{H}_{5}$ & $\mathrm{C}_{2} \mathrm{H}_{5}$ & $\mathrm{H}$ & - & 245 & 93 \\
\hline $19 \mathrm{~g}$ & $\mathrm{C}_{2} \mathrm{H}_{5}$ & $\mathrm{CH}_{3}$ & $\mathrm{C}_{2} \mathrm{H}_{5}$ & $\mathrm{H}$ & - & 245 & 94 \\
\hline $19 \mathrm{~h}$ & $\mathrm{CH}_{3}$ & $\mathrm{C}_{2} \mathrm{H}_{5}$ & $\mathrm{C}_{2} \mathrm{H}_{5}$ & $\mathrm{H}$ & - & 245 & 94 \\
\hline $19 \mathrm{i}$ & - & $\mathrm{C}_{2} \mathrm{H}_{5}$ & $\mathrm{C}_{6} \mathrm{H}_{5} \mathrm{CH}_{2}$ & $\mathrm{CH}_{3}$ & - & $229-231$ & 89 \\
\hline $19 j$ & - & $\mathrm{C}_{2} \mathrm{H}_{5}$ & $\mathrm{C}_{2} \mathrm{H}_{5}$ & $\mathrm{CH}_{3}$ & - & $219-220$ & 88 \\
\hline $19 \mathrm{k}$ & - & $\mathrm{C}_{2} \mathrm{H}_{5}$ & $\mathrm{C}_{6} \mathrm{H}_{5} \mathrm{CH}_{2}$ & $\mathrm{H}$ & - & $250-252$ & 90 \\
\hline 191 & $\mathrm{C}_{2} \mathrm{H}_{5}$ & $\mathrm{C}_{2} \mathrm{H}_{5}$ & $\mathrm{C}_{4} \mathrm{H}_{9}$ & $\mathrm{H}$ & - & 254 & 90 \\
\hline $19 m$ & $\mathrm{C}_{2} \mathrm{H}_{5}$ & $\mathrm{C}_{2} \mathrm{H}_{5}$ & $\mathrm{C}_{5} \mathrm{H}_{11}$ & $\mathrm{H}$ & - & 126 & 92 \\
\hline $19 n$ & $\mathrm{C}_{2} \mathrm{H}_{5}$ & $\mathrm{C}_{2} \mathrm{H}_{5}$ & $\mathrm{C}_{3} \mathrm{H}_{7}$ & $\mathrm{H}$ & - & $218-220$ & 82 \\
\hline 190 & $\mathrm{C}_{2} \mathrm{H}_{5}$ & $\mathrm{C}_{2} \mathrm{H}_{5}$ & $\mathrm{H}$ & $\mathrm{H}$ & - & 203 & 91 \\
\hline $19 p$ & $\mathrm{C}_{2} \mathrm{H}_{5}$ & $\mathrm{C}_{2} \mathrm{H}_{5}$ & $\mathrm{CH}_{3}$ & $\mathrm{H}$ & - & 296.5 & 86 \\
\hline $19 q$ & $\mathrm{C}_{2} \mathrm{H}_{5}$ & $\mathrm{C}_{2} \mathrm{H}_{5}$ & $\mathrm{C}_{2} \mathrm{H}_{5}$ & $\mathrm{H}$ & - & 178 & 90 \\
\hline $21 \mathrm{a}$ & - & - & $\mathrm{C}_{3} \mathrm{H}_{7}$ & $\mathrm{H}$ & $\mathrm{C}_{6} \mathrm{H}_{4} \mathrm{OH}-p$ & $252-255$ & 88 \\
\hline $21 b$ & - & - & $\mathrm{C}_{3} \mathrm{H}_{7}$ & $\mathrm{H}$ & $\mathrm{C}_{6} \mathrm{H}_{4} \mathrm{CH}_{3}-p$ & $215-218$ & 86 \\
\hline $21 \mathrm{c}$ & - & - & $\mathrm{C}_{3} \mathrm{H}_{7}$ & $\mathrm{H}$ & {$[|>\rangle$} & 210 & 65 \\
\hline $21 d$ & - & - & $\mathrm{C}_{3} \mathrm{H}_{7}$ & $\mathrm{H}$ & & $266-268$ & 80 \\
\hline $21 \mathrm{e}$ & - & - & $\mathrm{C}_{6} \mathrm{H}_{5} \mathrm{CH}_{2}$ & $\mathrm{CH}_{3}$ & $\mathrm{C}_{6} \mathrm{H}_{5}$ & $222-223$ & 92 \\
\hline $21 \mathrm{f}$ & - & - & $\mathrm{C}_{2} \mathrm{H}_{5}$ & $\mathrm{CH}_{3}$ & $\mathrm{C}_{6} \mathrm{H}_{4} \mathrm{OCH}_{3}-p$ & $226-228$ & 92 \\
\hline $21 \mathrm{~g}$ & - & - & $\mathrm{C}_{2} \mathrm{H}_{5}$ & $\mathrm{CH}_{3}$ & $\mathrm{C}_{6} \mathrm{H}_{5}$ & $207-209$ & 88 \\
\hline $21 \mathrm{~h}$ & - & - & $\mathrm{C}_{6} \mathrm{H}_{5} \mathrm{CH}_{2}$ & $\mathrm{H}$ & $\mathrm{C}_{6} \mathrm{H}_{5}$ & $239-240$ & 90 \\
\hline $21 \mathrm{i}$ & - & - & $\mathrm{C}_{4} \mathrm{H}_{9}$ & $\mathrm{H}$ & $\mathrm{C}_{6} \mathrm{H}_{4} \mathrm{CN}-\mathrm{O}$ & 206 & 89 \\
\hline $21 \mathrm{j}$ & - & - & $\mathrm{H}$ & $\mathrm{H}$ & $\mathrm{C}_{6} \mathrm{H}_{5}$ & $200-203$ & 60.83 \\
\hline $21 \mathrm{k}$ & - & - & $\mathrm{H}$ & $\mathrm{H}$ & $\mathrm{C}_{6} \mathrm{H}_{4} \mathrm{SO}_{3} \mathrm{H}-p$ & $198-201$ & 74.62 \\
\hline 211 & - & - & $\mathrm{H}$ & $\mathrm{H}$ & $\mathrm{C}_{6} \mathrm{H}_{4} \mathrm{OCH}_{3}-p$ & $158-161$ & 62.33 \\
\hline $21 \mathrm{~m}$ & - & - & $\mathrm{H}$ & $\mathrm{H}$ & $\mathrm{C}_{6} \mathrm{H}_{4} \mathrm{OCH}_{3}-p$ & $218-221$ & 64.68 \\
\hline $21 n$ & - & - & $\mathrm{H}$ & $\mathrm{H}$ & $\mathrm{C}_{6} \mathrm{H}_{4} \mathrm{Cl}-p$ & $207-210$ & 75.57 \\
\hline 210 & - & - & $\mathrm{CH}_{3}$ & $\mathrm{H}$ & $\mathrm{C}_{6} \mathrm{H}_{5}$ & 199-201 & 42.03 \\
\hline $21 p$ & - & - & $\mathrm{CH}_{3}$ & $\mathrm{H}$ & $\mathrm{C}_{6} \mathrm{H}_{4} \mathrm{SO}_{3} \mathrm{H}-p$ & $158-160$ & 90.46 \\
\hline $21 \mathrm{q}$ & - & - & $\mathrm{CH}_{3}$ & $\mathrm{H}$ & $\mathrm{C}_{6} \mathrm{H}_{4} \mathrm{COOH}-p$ & $158-160$ & 74.03 \\
\hline $21 \mathrm{r}$ & - & - & $\mathrm{CH}_{3}$ & $\mathrm{H}$ & $\mathrm{C}_{6} \mathrm{H}_{4} \mathrm{OCH}_{3}-p$ & $143-145$ & 82.54 \\
\hline $21 \mathrm{~s}$ & - & - & $\mathrm{CH}_{3}$ & $\mathrm{H}$ & $\mathrm{C}_{6} \mathrm{H}_{4} \mathrm{Cl}-p$ & $172-173$ & 65.05 \\
\hline $21 \mathrm{t}$ & - & - & $\mathrm{CH}_{3}$ & $\mathrm{H}$ & $\mathrm{C}_{6} \mathrm{H}_{4} \mathrm{OH}-p$ & $178-180$ & 35.88 \\
\hline $22 a$ & - & - & $\mathrm{C}_{6} \mathrm{H}_{5} \mathrm{CH}_{2}$ & $\mathrm{CH}_{3}$ & $\mathrm{C}_{6} \mathrm{H}_{5}$ & $280-282$ & 80 \\
\hline $22 b$ & - & - & $\mathrm{C}_{2} \mathrm{H}_{5}$ & $\mathrm{CH}_{3}$ & $\mathrm{C}_{6} \mathrm{H}_{4} \mathrm{OCH}_{3}-p$ & $245-246$ & 85 \\
\hline $22 c$ & - & - & $\mathrm{C}_{2} \mathrm{H}_{5}$ & $\mathrm{CH}_{3}$ & $\mathrm{C}_{6} \mathrm{H}_{5}$ & $241-243$ & 80 \\
\hline $22 d$ & - & - & $\mathrm{C}_{6} \mathrm{H}_{5} \mathrm{CH}_{2}$ & $\mathrm{H}$ & $\mathrm{C}_{6} \mathrm{H}_{5}$ & $180-182$ & 78 \\
\hline $22 \mathrm{e}$ & - & - & $\mathrm{C}_{4} \mathrm{H}_{9}$ & $\mathrm{H}$ & $\mathrm{C}_{6} \mathrm{H}_{4} \mathrm{CN}-\mathrm{O}$ & 263 & 95 \\
\hline 24 & - & - & - & - & - & $262-264$ & 66 \\
\hline 26 & - & - & - & - & - & $>300$ & 70 \\
\hline
\end{tabular}

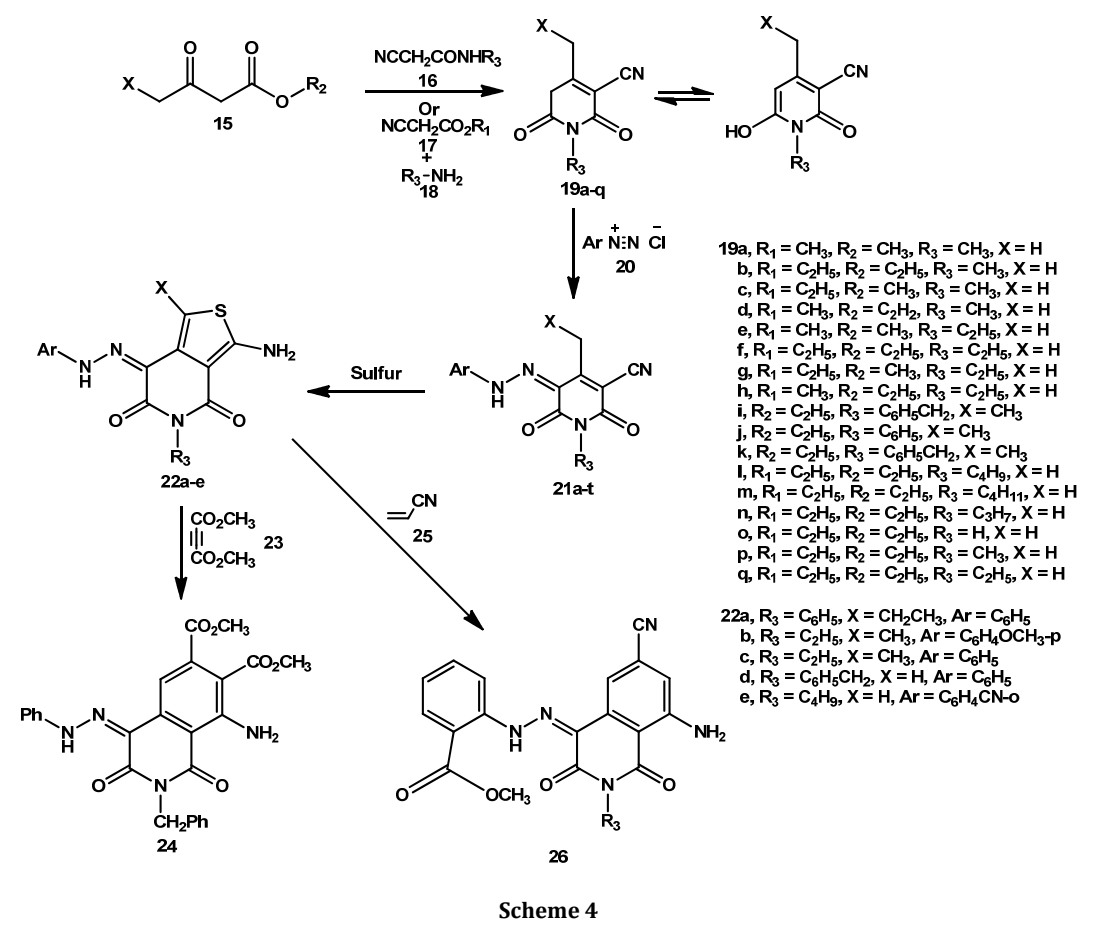


<smiles>CCc1c(N=[W])cccc1-c1ccccc1</smiles>

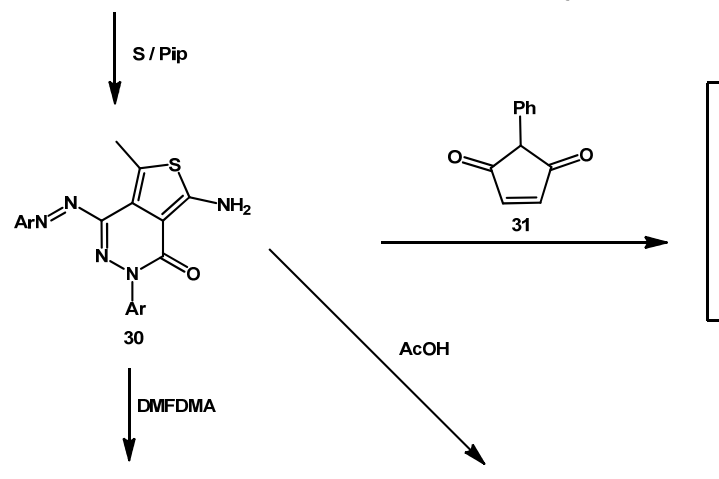

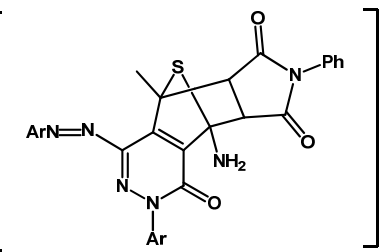<smiles>[3H][13CH2][13CH3]</smiles><smiles>Cc1sc(=N)nc2c1C(=O)c1c(N=CN(C)C)sc(C)c1-2</smiles>

34<smiles>CC(=O)Nc1sc(C)c2c(N=N)nn(C3CCCCC3)c(=O)c12</smiles>

35<smiles>Cc1c2c(c(N)c3c(=O)n(C4CCCCC4)nc(N=N)c13)C(=O)N(c1ccccc1)C2=O</smiles>

33

AcOH/ HCI

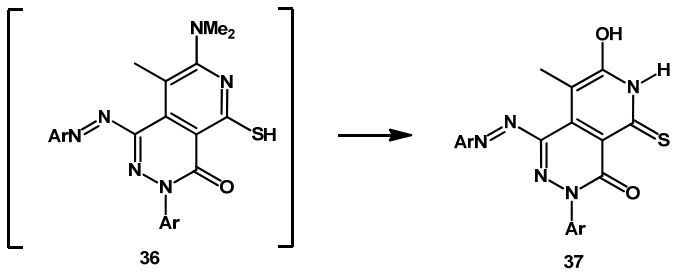

Scheme 5

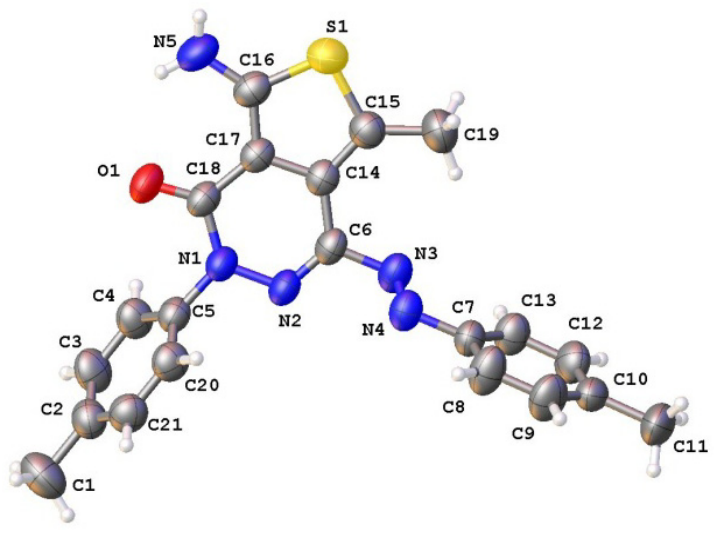

Figure 5. ORTEP drawing of compound 30.

Compound $\mathbf{3 8}$ was patented as dye for keratin fibers and compound $\mathbf{3 9}$ was patented by L'Oreal and other companies as constituent of a hair dye formulation. Moreover the biological activity of compound $\mathbf{3 8}$ has initially been patented by a Chinese group then published in Journal of Medicinal Chemistry in 2004 [57]. This information prompted us to continue investigating the potential utility of derivatives of both systems as antimicrobial dyes. Thus compound 42 was synthesized utilizing the approach similar to those utilized by Elnagdi et al. [58,59].



Figure 6. ORTEP drawing of compound 34. 


\begin{tabular}{|c|c|c|c|c|c|}
\hline Compound & $\mathbf{A r}$ & $\mathbf{A r}^{1}$ & $\mathbf{A r}^{2}$ & M.p. $\left({ }^{\circ} \mathrm{C}\right)$ & Yield (\%) \\
\hline $41 \mathrm{a}$ & $\mathrm{C}_{6} \mathrm{H}_{5}$ & - & - & $134-136$ & 74 \\
\hline $41 b$ & $\mathrm{C}_{6} \mathrm{H}_{4} \mathrm{Cl}-p$ & - & - & $183-185$ & 81 \\
\hline $41 c$ & $\mathrm{C}_{6} \mathrm{H}_{4} \mathrm{NO}_{2}-p$ & - & - & $140-142$ & 92 \\
\hline $41 d$ & $\mathrm{C}_{6} \mathrm{H}_{4} \mathrm{NHCOCH}_{3}-p$ & - & - & $215-217$ & 78 \\
\hline $42 a$ & $\mathrm{C}_{6} \mathrm{H}_{5}$ & - & - & $260-262$ & 54 \\
\hline $42 b$ & $\mathrm{C}_{6} \mathrm{H}_{4} \mathrm{Cl}-p$ & - & - & $270-270$ & 57 \\
\hline $42 c$ & $\mathrm{C}_{6} \mathrm{H}_{4} \mathrm{NO}_{2}-p$ & - & - & $255-257$ & 60 \\
\hline $42 d$ & $\mathrm{C}_{6} \mathrm{H}_{4} \mathrm{OH}-p$ & - & - & $245-246$ & - \\
\hline $42 \mathrm{e}$ & $\mathrm{C}_{6} \mathrm{H}_{4} \mathrm{NHCOCH}_{3}-p$ & - & - & $268-270$ & 70 \\
\hline 44 & $\mathrm{C}_{6} \mathrm{H}_{4} \mathrm{OH}-p$ & - & - & $287-288$ & 77 \\
\hline 46 & $\mathrm{C}_{6} \mathrm{H}_{4} \mathrm{OH}-p$ & - & - & $248-249$ & 70 \\
\hline $48 a$ & $\mathrm{C}_{6} \mathrm{H}_{4} \mathrm{OH}-p$ & $\mathrm{C}_{6} \mathrm{H}_{5}$ & - & $301-302$ & 76 \\
\hline $48 \mathrm{~b}$ & $\mathrm{C}_{6} \mathrm{H}_{4} \mathrm{OH}-p$ & $\mathrm{C}_{6} \mathrm{H}_{4} \mathrm{CH}_{3}-p$ & - & $309-310$ & 84 \\
\hline $48 c$ & $\mathrm{C}_{6} \mathrm{H}_{4} \mathrm{OH}-p$ & $\mathrm{C}_{6} \mathrm{H}_{4} \mathrm{Cl}-p$ & - & $306-307$ & 78 \\
\hline $48 d$ & $\mathrm{C}_{6} \mathrm{H}_{4} \mathrm{OH}-p$ & Fur-2-yl & - & $292-293$ & 80 \\
\hline $48 \mathrm{e}$ & $\mathrm{C}_{6} \mathrm{H}_{4} \mathrm{OH}-p$ & Thien-2-yl & - & $276-277$ & 80 \\
\hline $50 a$ & $\mathrm{C}_{6} \mathrm{H}_{4} \mathrm{NHCOCH}_{3}-p$ & $\mathrm{C}_{6} \mathrm{H}_{4} \mathrm{Cl}-\mathrm{O}$ & - & $310-312$ & 75 \\
\hline $50 \mathrm{~b}$ & $\mathrm{C}_{6} \mathrm{H}_{4} \mathrm{NHCOCH}_{3}-p$ & $\mathrm{C}_{6} \mathrm{H}_{4} \mathrm{~F}-p$ & - & $320-322$ & 75 \\
\hline $50 \mathrm{c}$ & $\mathrm{C}_{6} \mathrm{H}_{4} \mathrm{NHCOCH}_{3}-p$ & $\mathrm{C}_{6} \mathrm{H}_{4} \mathrm{OCH}_{3}-p$ & - & $240-242$ & 85 \\
\hline $52 a$ & $\mathrm{C}_{6} \mathrm{H}_{4} \mathrm{NHCOCH}_{3}-p$ & $\mathrm{C}_{6} \mathrm{H}_{4} \mathrm{Cl}-p$ & - & $330-331$ & 72 \\
\hline $52 \mathrm{~b}$ & $\mathrm{C}_{6} \mathrm{H}_{4} \mathrm{NHCOCH}_{3}-p$ & $\mathrm{C}_{6} \mathrm{H}_{4} \mathrm{~F}-p$ & - & $308-309$ & 73 \\
\hline $52 c$ & $\mathrm{C}_{6} \mathrm{H}_{4} \mathrm{NHCOCH}_{3}-p$ & $\mathrm{C}_{6} \mathrm{H}_{4} \mathrm{OCH}_{3}-p$ & - & $302-304$ & 79 \\
\hline $52 \mathrm{~d}$ & $\mathrm{C}_{6} \mathrm{H}_{4} \mathrm{NHCOCH}_{3}-p$ & $\mathrm{C}_{6} \mathrm{H}_{3} \mathrm{OCH}_{3}-p$ & - & 297-199 & 74 \\
\hline $54 a$ & $\mathrm{C}_{6} \mathrm{H}_{4} \mathrm{NHCOCH}_{3}-p$ & $\mathrm{C}_{6} \mathrm{H}_{5}$ & $\mathrm{C}_{6} \mathrm{H}_{4} \mathrm{OCH}_{3}-p$ & $320-322$ & 80 \\
\hline $54 \mathrm{~b}$ & $\mathrm{C}_{6} \mathrm{H}_{4} \mathrm{NHCOCH}_{3}-p$ & $\mathrm{C}_{6} \mathrm{H}_{4} \mathrm{Br}-p$ & $\mathrm{C}_{6} \mathrm{H}_{5}$ & $220-222$ & 80 \\
\hline $54 \mathrm{c}$ & $\mathrm{C}_{6} \mathrm{H}_{4} \mathrm{NHCOCH}_{3}-p$ & $\mathrm{C}_{6} \mathrm{H}_{4} \mathrm{Br}-p$ & $\mathrm{C}_{6} \mathrm{H}_{4} \mathrm{Br}-p$ & $308-310$ & 75 \\
\hline
\end{tabular}

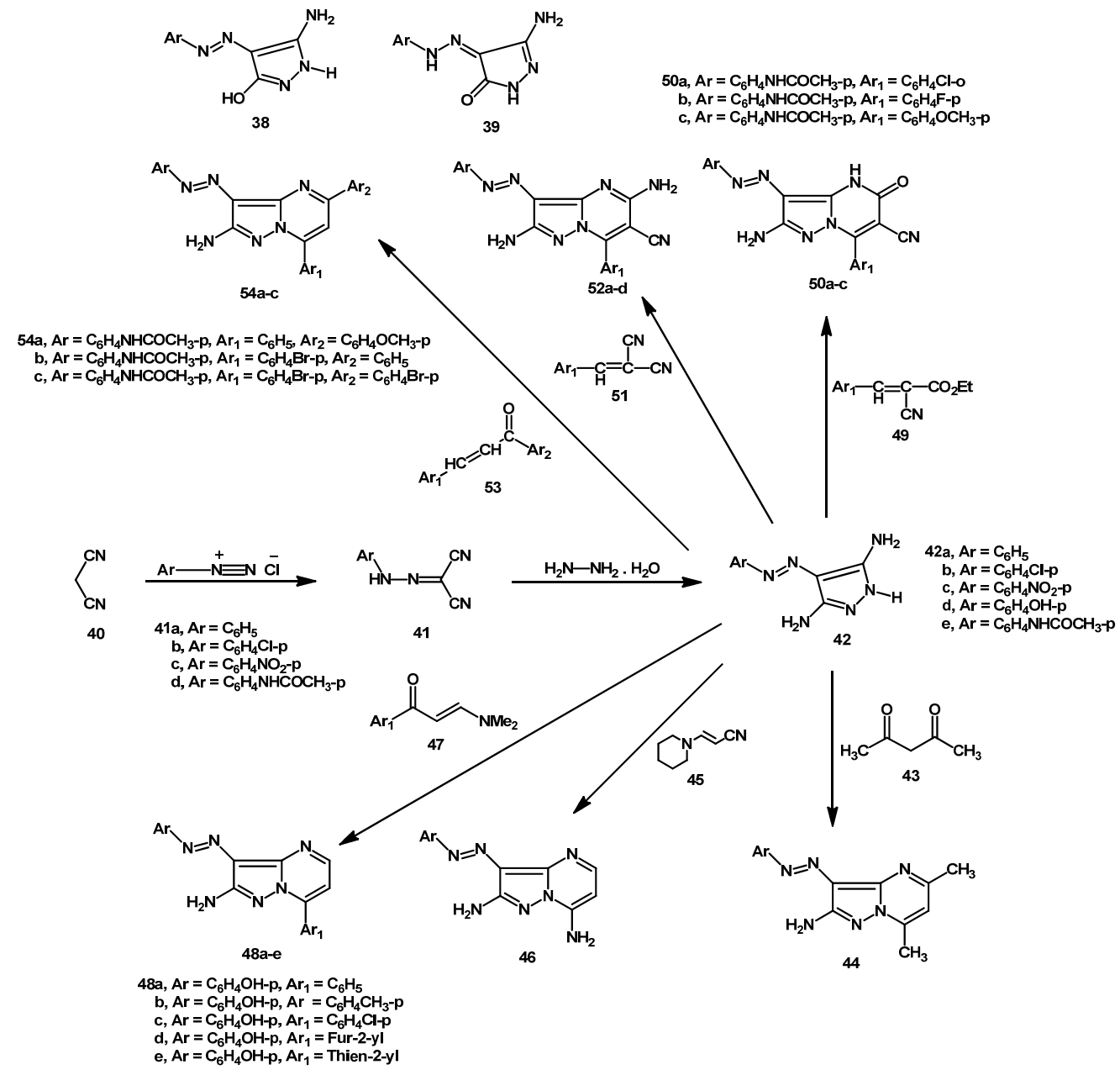

Scheme 6

Some other researchers [60-63] reported that coupling malononitrile $\mathbf{4 0}$ with aryldiazonium chloride afforded arylazomalononitriles, $\mathbf{4 1}$, that subsequently condensed with hydrazine hydrate to yield 4-arylazo-3,5-diaminopyrazoles, 42 Al-Etaibi et al. [62] has converted compounds 42 into a variety of pyrazolo(1,5-a]pyrimidines 44,46 and $48 a-e$ via 
condensation with 1,3-diketones $\mathbf{4 3}$, enaminonitriles $\mathbf{4 5}$, and enaminones 47 (Scheme 6).

Sayed et al. [63] has also converted compounds 42 into pyrazolo(1,5-a]pyrimidines 50a-c, 52a-d and 54a-c, however the structures of the products of addition of ethyl $\alpha$-cyano cinnamate derivatives 49 , arylidenemalononitrile $\mathbf{5 1}$ as well as reaction with chalcones $\mathbf{5 3}$ need confirmation as it contradicts with all reported data on similar systems. Although it was difficult in the past, now with availability of 2D NMR and ease of producing X-rays such structures can be readily confirmed.

The synthesized dyes 42a,b, 44, 46, 48a-d, 50a-c, 52a-d and 54a-c (Table 5) were applied successfully using high temperature dyeing method and obtained solid shades on polyester fabrics with satisfactory levelness of dyeing and depth of shades, the observed hues ranging from yellow to reddish-violet. The results of fastness properties showed in most cases acceptable to good fastness to light and washing fastness on the polyester fabrics. The antimicrobial activity of dyes 50a-c, 52a-d and 54a-c was also evaluated.

\section{Conclusion}

We have surveyed recently reported syntheses and dye characteristics of arylazonicotinates, arylazopyridones, arylazo pyridazinone as well as arylazopyrazoles emphasizing their promising potential as disperse dyes for polyester fabrics in the light of successful efforts that made their syntheses both environmentally green and economical methodologies as well as established antimicrobial activities of several newly synthesized dyes.

\section{Acknowledgements}

Support of this work provided by Kuwait University through a research grant (SC 05/09) and the facilities of GF-S, supported by research grants (GS01/01), (GS03/08), (GS01/03) and (GS01/05) are highly appreciated.

\section{References}

[1]. Berrie, A. H.; Hughes, N. ICI, DE-AS 1932 806, 1968.

[2]. Brandt, H.; Leverenz, K.; Otten, H-G. Bayer, EP 74 562, 1981.

[3]. Berrie, H. H.; Hughes, N. ICI, DE-OS 1932 806, 1970.

[4]. Seto, K.; Sekioka, R. Eur. Pat. Appl. 1992, EP 491386 A1 19920624.

[5]. Hunger, K. Industrial dyes: Chemistry, Properties, Applications, Willow-VCH, Germany, 2003, pp. 134-158.

[6]. Behbehani, H.; Abdel-Khalik, M. M.; Elnagdi, M. H. Org. Prepn. Proced. Int. 1999, 31, 551-557.

[7]. Abdel-Khalik, M. M.; Agamy, S. M.; Elnagdi, M. H. Synthesis 2001, 12, 1861-1865.

[8]. Al-Mousawi, S. M.; Moustafa, M. S.; Abdelshafy, I. A.; Elnagdi, M. H. Tetrahedron Lett. 2011, 52, 202-204.

[9]. Zaky, O. S.; Moustafa, M. S.; Selim, M. A.; El-Maghraby, A. M.; Elnagdi, M. H. Molecules 2012, 17(5), 5924-5934.

[10]. El-Apasery, M. A.; Al-Mousawi, S. M.; Mahmoud, H.; Elnagdi, M. H. Int. Res. J. Pure Appl. Chem. 2011, 1, 69-93.

[11]. Al-Mousawi, S. M.; El-Apasery, M. A. Molecules 2012, 17, 6547-6556.

[12]. Alnajjar, A.; Alsaiedi, M.; El-Apasery, M. A. Eur. J. Chem. 2013, 4(1), 5357.

[13]. Ashkar, A.; El-Apasery, M. A.; Touma, M.; Elnagdi, M. H. Eur. J. Chem. 2013, 4(3), 245-249.

[14]. Elnagdi, M. H.; Erian, A. W.; Sadek, K. U.; Selim, M. A. J. Chem. Res. 1990, 5, 148-149.

[15]. Gewald, K.; Hain, U. Synthesis 1984, 1, 62-63.

[16]. Al-Awadhi, H.; Al-Omran, F.; Elnagdi, M. H.; Infantes, L.; Foces-Foces, C.; Jagerovic, N.; Elguero, J. Tetrahedron 1995, 51, 12745-12762.

[17]. Abdelrazek, F. M.; Salah El-Din, A. M.; Mekky, A. E. Tetrahedron 2001, $57,1813-1817$.

[18]. Al-Omran, F.; Abdel Khalik, M. M.; Abou-Elkhair, A.; Elnagdi, M. H. Synthesis 1997, 91-94.

[19]. Al-Mousawi, S. M.; El-Apasery, M. A.; Mahmoud, H.; Elnagdi, M. H. Int. Res. J. Pure Appl. Chem. 2012, 2, 77-90.

[20]. Al-Mousawi, S. M.; El-Apasery, M. A.; Mahmoud, H. M. Molecules 2012, 17, 11495-11506.

[21]. Al-Qalaf, F.; Almohammad, K.; El-Apasery, M. A. Mahmoud, H. M. Eur. J. Chem. 2013, 4(3), 211-215.

[22]. Helal, M. H. Pigm. Resin Technol. 2004, 33(3), 165-171.
[23]. Bello, K. A. Dyes Pigments 1995, 28(2), 83-90.

[24]. El-Bayouki, M.; Abdel, H. K.; Asyouni, W. M.; Mohamed, Y. A.; Aly, M. M.; Abbas, S. Y. Eur. J. Chem. 2011, 2(4), 455-462.

[25]. Bach, V.; Hansen, G.; Lamm, G.; Sens, R. Eur. Pat. 1991, Appl. 413229

[26]. Ertan, N.; Gurkan, P. Dyes Pigments 1997, 33(2), 137-147.

[27]. Afanas'ev, I.; Korkina, L. G.; Kozlov, A. V.; Afanasev, I. B Phy. Chem. Bio. Med. 1996, 3(1), 25-30.

[28]. Chien, C. C.; Wang, I. J. Dyes Pigments 1991, 15(1), 69-82.

[29]. Okada, Y.; Hihara, T.; Morita, Z. Dyes Pigments 2008, 79(2), 111-125.

[30]. Okada, Y.; Hihara, T.; Morita, Z. Color. Technol. 2009, 125(2), 86-98.

[31]. Dikshit, D. V.; Deval, S. D.; Deodhar, K. D. Dyes Pigments 1985, 6(1), 3946.

[32]. Desai, V. R.; Patel, Dinesh; Desai, C. M.; Joshi, H. D. J. Inst. Chem. (India) 2000, 72(6), 228-229.

[33]. Wang, P. Y.; Wang, I. J. Text. Res. J. 1992, 62(1), 15-20.

[34]. Desai, V. R.; Patel, D.; Desai, C. M.; Joshi, H. D. J. Inst. Chem. (India) 2001, 73(3), 89-91.

[35]. Okada, Y.; Hihara, T.; Morita, Z. Dyes Pigments 2008, 78(3), 179-198

[36]. Jang, H. K.; Doh, S. J.; Lee, J. J. Fiber. Polym. 2009, 10(3), 315-319.

[37]. Gadre, J. N.; Periaswamy, R. M. S.; Mulay, M.; Vaze, C. S. Indian J. Heterocy. Ch. 2006, 16(1), 43-46.

[38]. Tietze, F.; Eicher, T. Reaction and Synthesis in the Organic Chemistry Laboratory, University Science Books, Mill Valley California, P359, 1989.

[39]. Katritzky A. R.; Rachwal, S.; Smith, T. P. J. Heterocycl. Chem. 1995 32(3), 1007-1010.

[40]. Gmaj, J.; Sosnaowski, C.; Zaremba, Z.; Mrowinski, B. Pol. Pat. 150312 Chem. Abstr., 1991, 114, 64264u.

[41]. Schmid, H. Ger offen D. E. 4,314,430, Chem. Abstr., 1995, 122: 31340c.

[42]. Balalaie, S.; Kowsari, E.; Hashtroudi, M. S. Monatsh. Chem. 2003, 134, 453-456

[43]. Balalaie, S.; Hashtroudi, M. S.; Sharifi, A. J. Chem. Res. 1999, 392-393.

[44]. Balalaie, S.; Arabanian, A.; Hashtroudi, M. S. Monatsh. Chem. 2000, 131, 945-948.

[45]. Balalaie, S.; Arabanian, A. Green Chem. 2000, 2, 274-276.

[46]. Balalaie, S.; Sharifi, A.; Ahangarian, B. Indian J. Heterocycl. Chem. 2000, $10,149-150$.

[47]. Balalaie, S.; Nemati, N. Heterocycl. Commun. 2001, 7, 67-72.

[48]. Balalaie, S.; Sharifi, A.; Ahangarian B.; Kowsari, E. Heterocycl Commun. 2001, 7, 337-340.

[49]. Elguero, J.; Marzin, C.; Katritzky, A. R.; Linda, P.; The Tautomerism of Heterocyles in Adv Heterocycl Chem, Academic Press New York 1, 1976, pp. 106-109.

[50]. Sakoma, K. J.; Bello, K. A.; Yakubu, M. K. Open J. App. Sci. 2012, 2, 5459.

[51]. Ashkar, S. M.; El-Apasery, M. A.; Touma, M. M.; Elnagdi, M. H. Molecules 2012, 17(8), 8822-8831.

[52]. Al-Mousawi, S. M.; Abdelhamidb, I. A.; Moustafa, S. M. Arkivoc 2007, 213-221.

[53]. Al-Zaydi, K. M.; Borik, R. M.; Elnagdi, M. H. Ultrason. Sonochem. 2009, $16,660-668$.

[54]. Al-Mousawi, S. M.; El-Apasery, M. A.; Al-Kandery, N.; Elnagdi. M. H. J. Heterocyclic Chem. 2008, 45, 359-364.

[55]. Al-Mousawi, S. M.; El-Apasery, M. A.; Elnagdi. M. H. Heterocycles 2008, 75(5), 1151-1161.

[56]. Al-Mousawi, S. M.; El-Apasery, M. A. Molecules 2013, 18, 7081-7092.

[57]. Zhang, Z.; Daynard, T. S.; Sviridov, S. V.; Chafeev, M. A.; Wang S. 2006. U. S. Patent, 7105503.

[58]. Elnagdi, M. H.; Kandeel, E. M.; Zayed, E. M.; Kandeel, Z. E. J. Heterocycl. Chem. 1977, 14(1), 155-158.

[59]. Elnagdi, M. H.; Fahmy, S. M.; Hafez, E. A. Z.; Elmoghayar, M. R. H.; Amer S. A. R. J. Heterocycl. Chem. 1979, 16(6), 1109-1111.

[60]. Tsai, P. C.; Wang, I. J. Dyes Pigments 2005, 64(3), 259-264.

[61]. Tsai, P. C.; Wang, I. J. Dyes Pigments 2007, 74, 578-584.

[62]. Al-Etaibi, A. M.; Al-Awadi, N. A.; El-Apasery, M. A.; Ibrahim, M. R. Molecules 2012, 17, 13891-13909.

[63]. Sayed, A. Z.; Aboul-Fetouh, M. S.; Nassar, H. S. J. Mol. Struct. 2012 1010, 146-151. 